\title{
Barbara Czarnecka
}

Uniwersytet Mikołaja Kopernika w Toruniu

\section{Kreacje kobiecości w (przedemancypacyjnej) narracji homoseksualnej Jana Lechonia}

\begin{abstract}
Simone de Beauvoir powiedziała w jakiejś analizie, że kobiety nie są jeszcze równouprawnione - tak samo jak Murzyni. To dobre porównanie, bo Murzyni też w całym szeregu dziedzin nie wiedzieliby, co zrobić z zupełnym równouprawnieniem, bo jako rasa są tak odrębni od innych, jak kobiety są przez swą płeć zupełnie różnymi psychicznie istotami niż mężczyźni. Nie znaczy to, żeby ograniczać Murzynów - ani tak się godzi, ani wcale tego nie trzeba (stając na stanowisku ich przeciwników). W Brazylii zupełnie równouprawnieni Murzyni wcale nie zabiegają np. o majątek. Po prostu wszystkie oszczędności wydają w czasie karnawału - tak że nie ma tam w ogóle Murzynów, którzy by się wznieśli materialnie nad średni dostatek ${ }^{1}$.
\end{abstract}

Jan Lechoń, notatka z 30 lipca 1951

W

powyższym fragmencie Dziennika Lechoń nawiązuje najprawdopodobniej do głośnej i kontrowersyjnej wówczas książki Simone de Beauvoir Druga płeć (Paryż 1949), która, stając się sztandarową pozycją feminizmu tzw. drugiej fali, naraziła się jednocześnie na zarzuty wykorzystywania perspektywy androcentrycznej i umacniania męskiego uniwersalizmu ${ }^{2}$. Notatka Lechonia postawiona w kontekście dzieła francuskiej pisarki uświadamia, że seksistowsko-rasistowski sąd wyartykułowany został w dobie kształtowania się nowoczesnej świadomości oraz niezwykłej aktywności ruchów społeczno-politycznych takich jak feminizm czy ruch praw obywatelskich. Wykreowane przez Lechonia literackie postaci kobiece odpowiadają wymaganiom dyskursu patriarchalnego, ale jednocześnie są efektem poszukiwania własnego obszaru homoseksualnej inności.

${ }^{1}$ Jan Lechoń, Dziennik, t. II, PIW, Warszawa 1992, s. 199.

${ }^{2}$ Wprowadzona przez de Beauvoir kategoria „inności” oznaczała reinterpretowanie kobiecości przez kategorie negatywne i podbudowę męskiego mitu. 
Współczesna (postemancypacyjna) literatura homoseksualna tworzy symboliczną przestrzeń wolną od kobiet ${ }^{3}$, co jednak nie musi mieć związku z mizoginią i odtwarzaniem dyskryminacyjnych i opresywnych schematów kultury patriarchalnej - taka jest teza Aleksandry Ambros, autorki posłowia do Klubu Korynckiego Alana Hollinhursta ${ }^{4}$. Inga Iwasiów, przywołując w tym kontekście pogląd francuskiej pisarki Marguerite Duras, wskazuje, że przyczyną tej nieobecności są: po pierwsze, poszukiwanie własnego obszaru Inności (homoseksualności), a dopiero po drugie, pewne patriarchalne klisze, od których nie sposób się odciąć: „Homoseksualista opowiada nam swą historię, mając świadomość kontynuacji, tropi znajome figury, teksty, aluzje, jest kronikarzem schadzek w łaźniach rzymskich i londyńskich. $\mathrm{Z}$ biografii poprzedników buduje całość, której istnienie dowartościowuje jego własne pożądanie" ${ }^{5}$. Inna sytuacja ma miejsce w przedemancypacyjnej (szyfrującej seksualność) literaturze homoseksualnej; tu figuracja kobiecości wiąże się z nachodzącym na siebie z dwóch stron, na mocy dwóch motywacji, wykluczeniem. $\mathrm{Z}$ jednej strony poprzez projekt takiej przestrzeni symbolicznej, która oddalałaby zarzut homoseksualności, identyfikowała z konstruktem męskości fundowanym przez patriarchalność (kobieta jako ornament, stereotypowy przedmiot seksualny), z drugiej strony przez podleganie tekstu Inności, homoseksualności podmiotu, którego pożądanie nie jest zorientowane na kobiecość. Jak pisze badaczka: „Kobieta jest dla homoseksualisty Innym, który nie przyzywa; Innym, który nie budzi pożądania" ${ }^{6}$. W twórczości Jana Lechonia figuracja ta uwarunkowana jest przez dwie przenikające się narracje: odpowiadającą schematowi patriarchalnemu oraz homoseksualną. Stwarza to pozornie stereotypowy porządek płci, rozpad świata przedstawionego na konwencjonalnie dualny: męski i kobiecy; podmiotem jest mężczyzna, i to on w rozmaitych, ale zawsze znaczących rolach, znajduje się w centrum uwagi poety, kobieta zaś stoi po stronie nieważności. Przyjrzyjmy się temu dokładniej.

${ }^{3}$ Literatura homoseksualna wydaje się wyznaczać kreacjom kobiecym pewną specyfikę. Piotr Sobolczyk wyróżnia w niej kilka archetypów kobiecości: „Można, jak mi się wydaje, wyróżnić pięć głównych Archetypów Kobiety w Literackim Świecie Gejów (oczywiście mogą się one krzyżować bądź postać może przechodzić z jednego archetypu w drugi): 1) Matka, 2) Przyjaciółka, 3) Żona, 4) Ideał, 5) Antyideał”. Typy kobiecości wskazane przez Sobolczyka odnoszą się do literatury, w której homoseksualność istnieje jako wątek jawny, stematyzowany, zatem do homoseksualnej literatury postemancypacyjnej. Zob.: Piotr Sobolczyk, Kobieta w (literackim) świecie gejów, [w:] red. Grażyna Borkowska, Lidia Wiśniewska, Beatrycze i inne. Mity kobiet w literaturze i kulturze, słowo/obraz/terytoria, Gdańsk 2010.

4 Zob.: Aleksandra Ambros, Mężczyźni bez kobiet, „Literatura na Świecie” 1992, nr 3.

5 Inga Iwasiów, Kobiecość w tekście homoerotycznym, [w:] red. Lidia Wiśniewska, Kobiety w literaturze. Materiały z II Międzyuczelnianej Sesji Studentów i Naukowców z cyklu „Świat jeden, ale nie jednolity”, Wyższa Szkoła Pedagogiczna, Bydgoszcz 1999, s. 196.

${ }^{6}$ Ibidem, s. 204. 
Za poetycki debiut Lechonia powszechnie uznawany jest Karmazynowy poemat (1920). Wyłączając Srebrne i czarne (1924), rządzące się nieco inną organizacją poetycką podporządkowaną intymnemu wątkowi nieobecności i kompleksowi winy, wyznacza on schemat treściowy i formalny poezji Lechonia, podjęty później w wierszach nowojorskich (1941-1956). „Karmazynowy poemat mówił o Polsce i polskości. Odwołując się do historii narodowej wyznaczał perspektywę współczesności. Jego utwory wyznaczone były przez «tu i teraz» losów społeczeństwa, z nich wyrastały i chciały je współtworzyć. Miały ambicję wypowiadania zbiorowych doświadczeń narodu, do nich się odwoływały"7. Tematy narodowe, problematyka polskich mitów, dyskurs patriotyczny powołują tu bohaterów męskich i to wokół nich zorganizowany jest świat przedstawiony wierszy. Stanowią oni uosobienie idei - politycznych, światopoglądowych, artystycznych, literackich; tworzą makrokosmos związanych z nimi „męskich” sensów. Problematyka tej poezji ewokuje mit tradycyjnej męskości, a jego podstawę stanowi mit narodowy. Antyromantyczny bunt w Herostratesie czy bitwa legionistów z wojskami carskimi pod Kostiuchnówką (3-6 lipca 1916 roku) w Polonezie artyleryjskim w sposób przewidywalny, zgodny z tradycyjną denotacją, nie włączają kobiecości. W Duchu na seansie w spirytystycznym spotkaniu z widmem Słowackiego uczestniczą „słuchacze mów pięknobrzmiących i dysput wygodnych”, spadkobiercy idei polskiego romantyzmu oczekujący utwierdzenia w jego ideach. Widmo jednak nie wypowiada oczekiwanego Słowa; sens przekazu jest zgoła nieoczekiwany i stanowi krytykę wyznawców romantyzmu. W tę metaforycznie przedstawioną ważną polską dyskusję zaangażowani są jedynie mężczyźni; kobieta jest nieobecna.

Podobny status kobieta ma w całej twórczości Lechonia. Znajduje się poza tym, co stanowi treść światopoglądową i pozwala odgrywać zaangażowane społecznie role, jest projekcją poglądu wyrażonego w Dzienniku:

Któż by miał dziś odwagę powiedzieć głośno, że kobieta stoi zasadniczo intelektualnie niżej od mężczyzny? Ja też tego nie myślę, ale myślę, że jest ona kimś zupełnie innym, że pewne abstrakcje są dla niej niemożliwe do pojęcia, że mimo pani Curie, mimo Sigridy, którą uważam za jednego z największych pisarzy naszej epoki - intelekt nie jest to świat kobiety. Kobiety są idealnymi rządcami: Elżbieta, Katarzyna, Wiktoria, Wilhelmina - czyż trzeba więcej na to dowodów? Ale właśnie rządzenie nie wymaga intelektu, tylko tzw. zdrowego rozsądku i daru decyzji, która polega często na przezwyciężeniu najsłuszniejszych wątpliwości. Przyznam się, że nie rozumiem artystów, na których kobiety wpływają inaczej niż przez uczucie czy po prostu łóżku. I myślę, że Krasiński pisał o Delfinie jako o swojej Muzie w tym właśnie znaczeniu, tylko ubierał to w różne galanterie, aby podziękować elegancko Delfinie za czarujące raczej noce niż wieczory. Dyskusje z kobietami o Pascalu czy Bergsonie - cóż za okropieństwo.

7 Roman Loth, Wstęp, [w:] Jan Lechoń, Poezje, Zakład Narodowy im. Ossolińskich, Wrocław 1990, s. L. 
O psychoanalizie - to co innego, bo to przecież zwyczajne plotki, tylko w naukowym opakowaniu $^{8}$ (notatka z 19 kwietnia 1950).

Nie oznacza to, że figurację kobiecości całkowicie wchłonął mizoginiczny stereotyp, nosi ona raczej wyraźną sygnaturę wyobraźni Lechonia.

\section{Nieważność: Bal u senatora}

W konstelacjach relacji głównie męskich bohaterów Balu u senatora, nigdy nieukończonej, a znanej jedynie z kilku fragmentów powieści Lechonia9 ${ }^{9}$ postać kobieca znajduje się na marginesie nieważności:

że ci ludzie, niezdolni zrozumieć dwu taktów z jego Bolesława Śmiałego, naprawdę lubili jego towarzystwo i rozmawiali z nim, nie, broń Boże, o muzyce, ale właśnie o koniach i kobietach, było dla Okęckiego jak gdyby pasowaniem go na kogoś, kim w podświadomości swej chciał być przede wszystkim; dzięki przyjaźni tych ludzi, dzięki złudzeniu możliwego z nimi porozumienia, wydawał się sobie chwilami Okęcki człowiekiem jak wszyscy inni [BS, s. 8].

Wykreowaniu człowieka „takiego jak inni”, wpisaniu go w obiegową uniwersalną normę, służą rozmowy o koniach i kobietach - w takiej właśnie kolejności. Podobną zasadę upodrzędniania postaci kobiecej da się zaobserwować w liryce Lechonia. Fragmenty Balu w operze aspirowały jednak do powieści w duchu Proustowskim, z rozwiniętymi wątkami psychologicznej obserwacji. Ten dość nietypowy dla Lechonia typ twórczości stanowi, choć nieobfity, jednak interpretacyjnie interesujący materiał. Opisowe, narracyjnie rozbudowane ujęcia oraz eksplikacja motywacji psychologicznych pozwalają zobaczyć kobietę wykreowaną poza liryką, choć w nieco innych niż tam ujęciach i kontekstach, jednak zasadniczo o podobnych rysach nieważności.

Akcję fragmentów powieści prowadzą wyraźnie zarysowani bohaterowie męscy; kobiety usytuowano na poboczach fabuły, na przykład w roli obiektu czasowej, estetycznej i snobistycznej fascynacji:

8 Jan Lechoń, Dziennik, t. I, PIW, Warszawa 1992, s. 272-273. Nieco wcześniej czytamy: „Bardzo miła, dobra, bardzo kobieca, o idealnym usposobieniu pani powiedziała mi wczoraj: «Niech pan zapomni o tym, że to ja powiedziałam, ale muszę panu zdradzić wielką tajemnicę. Jeśli z jakiejkolwiek kobiety coś wyszło dobrego, jeśli ja jestem, czym jestem, to dlatego, że mężczyźni używali na nas bata.» I tutaj zacytowała swego męża, prawdziwego tyrana, którego wybryki oburzają wszystkich: «Jemu to, czym jestem, zawdzięczam.»” [s. 271]..

9 Jan Lechoń, Bal u senatora: Fragmenty nie ukończonej powieści, Czytelnik, Warszawa 1981. Fragmenty opracował Tadeusz Januszewski. Tekst powieści oparty został na pierwodrukach fragmentów w czasopismach: fragment 1 - „Wiadomości Polskie, Polityczne i Literackie” 1942, nr 27; fragment 2 - „Tygodnik Polski” 1944, nr 32; fragment 3 - Wiza do Ameryki, „Wiadomości” 1950, nr 14/16; fragment 4 - Opowiadanie Czaplica, „Wiadomości” 1948, nr 51/2. Wszystkie cytaty, z sygnaturą BS, podaję za tym wydaniem. 


\begin{abstract}
Na jej twarzy nie było już teraz owych brzoskwiniowych rumieńców, w których dziesięć lat temu zakochał się Kamil, szarosrebrne pasma zakradły się między jej lśniące brązowe włosy, w kącikach ust, w spojrzeniu jej ogromnych oczu czaiły się teraz zmęczenie i niepokój. Nic już prawie nie zostało w Bronce z owej wyniosłej, tajemniczej piękności, o której Kamil ledwie odważał się marzyć, pewien, że może ona przebierać do woli między wszelkimi odmianami doskonałego szczęścia. Teraz była to już inna Bronka, nie mająca w sobie żadnych powieściowych tajemnic, żadnych blasków światowej świetności, w które ją stroiły marzenia Kamila. Jej oczy nie wydawały już niemych rozkazów życia, nie świeciły już w nich dawne ognie buntu, w jej uśmiechu nie było już dawnej pogardy dla zwykłych zdarzeń i szarych ludzi [BS, s. 33].
\end{abstract}

Taką Bronkę stwarza spojrzenie Kamila; w tym wizerunku ścierają się pospolitość z nadzwyczajnością i niewiele zostaje z kobiety, jeśli nie ma w niej już „żadnych blasków światowej świetności”. Te „blaski” mają ewidentnie estetyczny charakter: przemijająca uroda w kolorystycznym ujęciu (brzoskwiniowe rumieńce, lśniące brązowe włosy), wyniosłość tajemnicy (bycie poza realnością), władza (może wybierać) i - co dla Lechonia stanowi zwykle doniosły argument - światowość, poza tym mało efektowne zmęczenie i starzenie się; oto „inna Bronka”. Mimowolnie, w szczelinie narracji ujawnił autor realistycznie widzianą kobietę jako - dosłownie - Inną. Z Inności wyrywa ją tylko ów estetyczno-snobistyczny naddatek, wynosi, sentymentalnie uwzniośla, i, co ważne, pochodzi z nadania mężczyzny, jest męskim fantazmatem - „ją stroiły marzenia Kamila”. Męskość jako punkt odniesienia, kulturowy model, i kobiecość jako pochodna męskiego fantazmatu są oczywistym wątkiem patriarchalności. Bronka wpisuje się w tę patriarchalną matrycę wyobraźni wręcz modelowo; to postać unieważniająca samą siebie, samounicestwiająca w emocjonalnej relacji z mężczyzną, skupiona tylko na nim:

Ale z wprawą nabytą w tylu z nim rozmowach, w których myślała tylko o tym, aby on nie zatroszczył się o jej smutki, przełknęła dławiące ją łzy i szła z wzrokiem utkwionym przed siebie, aby Kamil mógł do końca uśmiechać się do już teraz na pewno nie mających się wypełnić swoich obietnic [BS, s. 33].

Kobiecość nosi tu rys autodestrukcji, skłonność do samozatraty tkwi w niej immanentnie, mężczyzna nie jest jej winien. Niespełnione obietnice i zdrady Kamila tłumaczą się taką właśnie bezbarwną, bezosobową Bronką. (Odzwierciedla to problem masochizmu w ujęciu Zygmunta Freuda - lekceważenie i poniżenie kobiety jest tym, czego ona się domaga.) Jej tani ubiór, kapelusz wykonany własnoręcznie, nie budzą tkliwości w Kamilu, wciągają go w rozważania o samym sobie, własnej szlachetności:

Kamil trzymając ją pod rękę, spoglądał wciąż ukradkiem na jej dobrze skrojony, ale ubogi popielaty kostium, na jej taniusi kapelusz, który sama sobie zrobiła, i myślał, o ile lżej 
byłoby mu teraz, gdyby był jej kupił ów płaszczyk podbity futrem, który jej obiecał na gwiazdkę, niepewny, czy będzie mógł dotrzymać obietnicy. [...] Teraz przychwyciwszy jego spojrzenie na ów kapelusz, o którym wiedziała, jak bardzo był pospolity, zrozumiała nagle, że tak jak Kamil przed nią, ona nigdy przed jego wciąż czujną, a bezradną miłością nie zdołała ukryć niczego, że nie umiała go oszukać, że jest szczęśliwa, że nie ciąży jej praca, że naprawdę nie zależało jej na tym płaszczyku podbitym futrem [BS, s. 32-33].

Kamil „spogląda ukradkiem”, patrzy z ukosa, z boku, kątem, krytycznie. Bronka jest tutaj podglądana, nie w empatycznym zainteresowaniu czy erotycznej ekscytacji, ale okiem obserwatora, które śledzi niedostatki, niedoskonałości i z nich buduje własną emocjonalną figurę. Czujne spojrzenia obojga (,[Bronka - B.C.] przychwyciwszy jego spojrzenie”) krzyżując się, wyznaczają relację trudno zrozumiałą, chyba męczącą dla obojga.

Wąskie i ograniczone są te przestrzenie, które wyznacza kobiecości Lechoń. Kobiety pojawiają się w szczelinie męskiego losu, obdarzone istnieniem i znaczeniem głównie za przyczyną męskiej pamięci (nigdy pożądania); jest to wywołanie czasowe i o charakterze fantazmatycznym. Bohaterowie męscy istnieją autonomicznie przez swoje projekty, talenty, idee lub przeszłość (Kamil - wstąpienie do wojska i służbę ojczyźnie; Kątski - komponowanie; Czaplic - heroiczną młodość), kobiety nie mają swojej herstory, własnej przestrzeni aktywności; czasem wprowadzane są wręcz jako przestrzenie nieobecności. Dwie miłości Okęckiego z pierwszego fragmentu powieści, Irena (umarła) i Maria (odeszła), to miłości niespełnione, istniejące jedynie jako figura pustki, nieistnienia. Irena była miłością młodzieńczą, nieodwzajemnioną, która umarła młodo:

Irena, którą kochał, gdy miał lat dwanaście, która nigdy nie mogła go kochać, bo całym porywem swego prostego serca kochała kogo innego, stała oto przed nim tak wyrazista, tak żywa, jakby to było wczoraj to popołudnie na pensji, na które go prosiła, by przyszedł posłuchać owego Tria, które miało być grane potem na pensjonarskim koncercie. Jakże mógł o niej nie myśleć, jak mógł ją zapomnieć, jak to się stać mogło, że ona umarła jak w sentymentalnej powieści i on był na jej pogrzebie, i nie myślał o niej albo raczej myślał same nieżywe, niejako przepisane do myślenia w takich chwilach rzeczy! [BS, s. 20]

Ale nawet to fantazmatyczne istnienie Ireny jest niedokończone, niecałe. Szukając obrazu jej twarzy, ciała, postaci rzekomo wyrazistej, „tak żywej, jakby to było wczoraj”, odnajdujemy zaledwie obraz ubrania i skrzypce:

Irena stała oto przed jego wzrokiem, ubrana w czarny pensjonarski swój mundurek, z głową opartą o skrzypce, a za nią była zasłona zasnuwająca w swych fałdach całe jego życie, od chwili, gdy zrozumiał, że Irena go nie kocha, do tej chwili, gdy po raz drugi zapragnął wypełnienia się swej miłości [BS, s. 21]. 
Mamy ubranie zamiast cielesności, grę na skrzypcach jako przeniesienie postaci w odrealnioną sferę artystostwa (choć tylko na pensjonarskim poziomie), uwznioślenie, które niweluje odwołania do cielesności.

Podobnie obecna/nieobecna, zupełnie bez ciała jest Maria. Najbardziej namacalny ślad jej obecności w powieści to list do Okęckiego. Staje się on substytutem osoby, jej realności, spełnienia: „dostał - ach! Jakże tę chwilę dobrze pamiętał - od niej list, który długo pieścił wzrokiem i w porywie czułości gładził ręką, zanim poszedł w aleję parkową, by go odczytać” [BS, s. 21] - zatem spojrzenie, pieszczota i poszukiwanie intymności odnoszą się do listu, a nie do osoby. Spotkanie z pismem nie ucieleśnia spotkania z Marią, rozgrywa się zamiast niego, jest odejściem od jej ciała i seksualności, uniknięciem jej. Tym samym Maria, bezcielesna, reprezentowana przez pismo „według brzmienia wiekowego zwyczaju" ${ }^{10}$, podlega autorytetowi męskiemu:

List pełen był niewątpliwego wysiłku, by podobać się Okęckiemu, pełen wyrażeń sztucznie lekkich i właściwie dobranych tak nieszczęśliwie, że w każdym innym wypadku tego by starczyło, aby Okęcki zraził się na zawsze do osoby silącej się na styl przeciwny jej naturze. Okęcki odczuł tę sztuczność od pierwszego słowa, i pierwszym odruchem jego myśli było rozczarowanie i zaraz za nim idące poczucie, że łatwiej, niż myślał, przyjdzie mu zapanować nad istotą obarczoną tak wyraźnymi słabostkami, poczucie, w którym był tyle mu znany posmak znudzenia niewątpliwym, a więc niegodnym walki zwycięstwem [BS, s. 21-22].

Kobiecy list jest pismem „niefortunnym”, „niezręcznym”, a jego autorka „obarczona tak wyraźnymi słabostkami”. W odruchu zniechęcenia Okęckiego słychać echo mizoginicznej krytyki literackiej z przełomu XIX i XX wieku i męski projekt kobiety-autorki definiowany przez ułomność, brak ${ }^{11}$. Zatem ciało i pismo kobiece wkracza w inność. „Kobieta - autor pozostaje poza tymi [tradycyjnymi - B.C.] relacjami i rolami, a więc także poza tożsamością swej płci, która ulega zachwianiu"12. Lechoń projektuje tu bohatera męskiego,

${ }^{10}$ „WWedług brzmienia wiekowego zwyczaju - ironizował Świętochowski - nauka ich to blichtr, talent - pretensjonalność, chęć działania to szaleństwo. [...]» W pisaniu kobiety «objawia się» pycha, lekceważenie narzuconej od wieków pokory. Wchodząc przez pisanie w przestrzeń publicznego mówienia-działania, kobieta wydobywa się z milczenia i ciszy. Zakłóca tradycyjny podział ról społecznych pomiędzy kobietą a mężczyzną, ustaloną hierarchię, słowem relacje władzy”. Cytuję za: Krystyna Kłosińska, Ciało, pożądanie, ubranie: O wczesnych powieściach Gabrieli Zapolskiej, „eFKa”, Kraków 1999.

${ }_{11}$ „Definiowany przez «brak» tekst kobiecy zostaje utożsamiony z defektem, ułomnością, niekompletnością (kastracją?). Cechę kompletności, pełni, mają wytwory męskie. Opis i wartościowanie dwóch typów literackiej twórczości posługujące się słowem «brak» budzi od razu skojarzenia z Freudem i jego projekcją «bytu kobiecego». Kobietę (jak jej płeć) definiuje u niego «brak»: tego, co ma mężczyzna (byt pełny doskonały, zarówno pod względem uposażenia intelektualnego, jak i fizjologii)”. Ibidem, s. 16.

12 Ibidem, s. 9. 
który w istocie nie spotyka się z kobietą, albo spotyka się z nią jedynie we własnym fantazmacie, w którym w końcu „zobaczył pismo inne, niewidzialne pismo prawdziwej Marii, zdolne oddać jego uczucia takimi, jakimi były naprawdę, pismo doskonałe, którego nie można było tłumaczyć rozmaicie, a które on jeden tylko potrafił odczytać" [BS, s. 22]. Rezygnacja z ukonkretnionej, zindywidualizowanej kobiecości, a właściwie ekwilibrystyka uników i unieważnień, prowadzi do kreacji odzwierciedlającej męskie oczekiwania, wizję i potrzeby przekazu (pisma), którego koncept trudno uchwycić. Irena i Maria - postaci zapowiedziane, ale niewykreowane, niewiadome jako wyobrażalne osoby - w zasadzie pozostają w tekście nieobecne. Włączone w narrację jako element heteroseksualnej historii nie ucieleśniają się, narracja unieważnia w ten sposób „prowokującą realność” ${ }^{13}$ kobiecego ciała.

Odbiega od tego wzorca postać Reny Łączyńskiej w czwartej części, Opowiadanie Czaplica. Jest to jedyna w powieści kreacja nie pomijająca kobiecej cielesności:

Rena Łączyńska była to kobieta pełna zdrowego uroku, w którym subtelni komplemenciści dopatrywali się perwersyjnego połączenia polskich wsiowych czarów z jakimś renoirowskim kolorem. Była prawie za duża, za rosła, ale ten jej wzrost, jej nos wydatny i szerokie usta przy ruchach pełnych gracji, melodii altowego głosu, wspaniałych kasztanowych włosach, tworzyły doskonałą, pełną zmysłowego uroku harmonię. I teraz szczególnie, w białej krynolinie z olbrzymim pękiem liliowych orchidei, mogła Rena przedstawiać zarazem zdrowie polskiej rasy i szyk Paryża z tych najlepszych lat dziewięćsetnych [BS, s. 68].

Cielesność Reny tworzy obraz estetyczny, w którym doniosłą rolę gra kolorystyka, fason sukni i dobrane do niej kwiaty; obecność tych przedmiotowych składników i ich szczegółowe przedstawienie można uznać za schematyczne w narracji poetyckiej i prozatorskiej Lechonia. Rena, „prawie za duża, za rosła”, wychodzi poza ideał kobiecej kruchości i filigranowości. Posągowość sylwetki i typ urody umieszczają tę kreację blisko malarskich przedstawień Jacka Malczewskiego, figuracji kobiet o mocnej budowie oraz wyraźnych, nieraz grubych rysach twarzy. Nie tylko jednak ten kobiecy fenotyp łączy ujęcie Lechonia z dziełem Malczewskiego, pokrewne jest także wprowadzenie połączonego z postacią kobiety tematu polskiego. Siłą, a jednocześnie główną zaletą, bohaterki Lechonia jest polskość - „Była ona najpoczciwszą osobą jak wszystkie Polki, Polką fanatyczną; oburzenie na Niemców i troska o los kraju były to jej uczucia prawdziwe i głębokie" [BS, s. 68]. Na towarzyskim spotkaniu dyplomacji w Brazylii Rena, żona polskiego radcy, występuje w roli orędowniczki narodowej sprawy. Wydaje się, że Lechoń

${ }^{13}$ Określenie Georgesa Bataille’a. Zob.: Georges Bataille, Historia erotyzmu, przeł. Tadeusz Kania, Oficyna Literacka, Kraków 1992, s. 129. 
chce zobaczyć Renę w roli alegorii Polski, choć jej realizm niweluje znaczenia symboliczne. Polska wcielona jest w kobietę pełną niedoskonałości i wad: „Niestety, ta najzacniejsza i piękna kobieta miała w tym swoim apostolstwie jakieś natręctwo, jakąś płynność, jakiś posmak fachowości, odbierające całą dramatyczność prawdziwym dramatom, które opowiadała i którymi chciała wzruszyć swoich rozmówców" [BS, s. 68]. Bez wyczucia sytuacji, jakby nie orientując się w zasadach salonowego savoir vivre'u, nie potrafi też Rena sprostać intelektualnym wymogom eleganckich dyskusji:

Na biedną Renę uderzyły poty, poczuła bowiem, iż Benard kieruje rozmowę na takie wyżyny i abstrakcje, że nie sposób będzie się jej na nich utrzymać i że będzie musiała po prostu wycofać się z dyskusji, aby uniknąć kompromitacji. Nie bardzo rozumiała, co Benard miał na myśli, mówiąc o Mickiewiczu, i to już zbiło ją z tropu. Że zaś ze światowego obowiązku wiedziała, iż jest on wielkim specjalistą od św. Tomasza z Akwinu, więc nagle przyszło jej do głowy, że może on zacząć mówić o nim i że wtedy okaże się, jak to nieraz dawno temu bywało na pensji, że ona absolutnie nic o takim świętym nie wie [BS, s. 70].

Rena pozbawiona jest elokwencji, erudycji i dowcipu. Autor wyposaża jednak bohaterkę, „tę pozbawioną wyobraźni naturę” [BS, s. 72], w pozawolicjonalny imperatyw histerii. Rena wybucha, wywołuje skandal, rzec można polski, występuje na rzecz Polaków gwałtownie, w sposób dla niej samej nieprzewidywany:

Krew uderzyła jej do głowy, nie wiedząc sama, co robi, popełniając to, co minutę temu uważałaby za największy skandal [...] powiedziała, a raczej zawołała: [...] To wstyd, to wstyd co Pan robi. Głos jej [był - B.C.] ostry, podniecony i prawdziwy, jakiego nie słyszy się w salonach [...] Tam mordują ludzi! Mordują chrześcijan, jak za Nerona! [BS, s. 74].

Bohaterka wyrasta tu na olbrzymkę wyposażoną w energię histerii, wydobywa „prawdziwy”, donośny i doniosły głos, paraliżuje kurtuazyjny konwenans, dialektykę salonu, krzyczy i nie pozwala sobie przerwać. Jej postać stanowi niemal freudowskie studium: ubezwłasnowolniona przez obyczajową, salonową normę, unieważniona wyniosłością i obojętnością męskiego w dużej mierze otoczenia, buntuje się krzykiem, gwałtowną narracją, która poczytywana jest za szaleństwo. („Czyś ty oszalała?” - pyta jej mąż.) Tylko, że ten spazm to trybut na rzecz polskości, polski afekt, krzyk ubezwłasnowolnionych Polaków pod okupacją, których głos wzywający pomocy ginie w gwarze pustych salonowych rozmów. Wrzask Reny wyraża sprawę polską, a nie ją samą. Poza tym aktem ekspresji Reny w zasadzie nie ma, nie istnieje ona dalej, autor wyprowadza ją, usuwa poza fabułę powieści. „I poszła, szybko szeleszcząc jedwabiami od Lanvina, by w pokoju Józefowej upaść na jej łóżko i znów, jak tyle razy w ostatnich miesiącach, tłumić jakieś babskie wiejskie 
zawodzenia” [BS, s. 75]. Ważność, alegoryczność Reny trwa do momentu, kiedy przestaje ona udzielać głosu sprawie polskiej. Afirmowana uprzednio cielesność Reny nie należy do niej samej, zaangażowana jest w kształtowanie wizerunku Reny posągowej, alegoryzowanej. Pomnikowe ciało współkształtuje pomnikowy temat polski, poza którym wątek postaci Reny urywa się. W powieściowych fragmentach pełni on jeszcze funkcję prologu do opowieści Czaplica (podania o heroicznych losach polskiego patrioty):

W słowach Reny, słuchem zaprawionym przez dziesięć lat samotności do łowienia dźwięków niedosłyszalnych dla ludzkich uszu, usłyszał jakby głos tych wszystkich, którzy ginęli teraz w takich jak on niegdyś mrokach, w męczarniach, których granicy on nie znał, ale o których on jeden miał tutaj pojęcie [BS, s. 77].

Lechoń nie udziela głosu kobiecie, a sprawie polskiej. Rena nie może mieć ciała seksualnego, bo jako alegoria kobiety-Polski musi zachować niewinność. Wyraża się tutaj typowy dla Lechonia dualizm tego, co wysokie, święte, narodowe i tego, co niskie, ciemne, cielesne. Posągowość ciała pozostaje aseksualna, a mająca cielesne źródło impulsywność odpowiada gwałtowności emocji patriotycznej ${ }^{14}$. Rena w idealistycznym uniesieniu, występująca wbrew realnie obowiązującym zasadom, utożsamia wyznawany przez Lechonia ideał duszy polskiej. Po wypełnieniu alegorycznej, wzniosłej roli formalnie kończy się jako postać powieści. Nie przypadkiem kobiecie przypisał Lechoń, co prawda szlachetną, ale histeryczną reakcję. Rena wciela kompleks bezradności, poczucie własnej nieważności, przeświadczenie o braku intelektualnych możliwości. Jej wybuch temu nie przeczy, nie unieważnia jej defektów i jest częścią ciemnej, zagmatwanej inności, tak odmiennej od Lechoniowych kreacji mężczyzn. Ci są klarowni, intelektualni, obdarzeni talentem, mają swoją heroiczną history.

Kobieca nieważność wyraźnie zaznacza się na tle męskiej enklawy. Wzniosłe, istotne i bliskie rozmowy toczą się tylko między mężczyznami. Przestrzeń męskości jest przestrzenią obecności sensów i idei:

Kamil nie widział go [Kątskiego - B.C.] od swego pobytu w Paryżu na Boże Narodzenie i zobaczywszy go zrozumiał, że właściwie od tego dnia z nikim naprawdę nie mówił o najważniejszych dla siebie sprawach. Zakosztowawszy przed paru laty w tych rozmowach, Kamil z młodzieńczą niezdolnością do pobłażania lekceważył odtąd wszystkie inne, nawet te, w których dawano mu najszczerzej, prawda, że najczęściej też niezgrabnie poczciwą o niego troskę, Kątski bowiem był jedynym dostępnym Kamilowi człowiekiem, z którym mówiąc, zapominał on o dokuczliwościach życia [BS, s. 35].

${ }_{14}$ Zob.: Maria Janion, Bogini Wolności (dlaczego rewolucja jest kobieta), [w:] eadem, Kobiety i duch inności, Wydawnictwo Sic!, Warszawa 2006, s. 5-50. 
W relacji między Kamilem i Kątskim rozkwita platońska wspólnota ducha i wyczerpują się najważniejsze uczucia.

Kątski od chwili, gdy zdołał się skupić na rozmowie z Kamilem, zaczynał pojmować to, nad czym nigdy prawie dotąd nie myślał, że wśród owej hucznej pustki, która go otaczała, podziw Kamila Hozjusza, szlachetna ufność, jaką on w nim pokładał - były to rzadkie uczucie prawdziwe, które mogły go nigdy nie zawieść [BS, s. 37].

„Z nikim”, „nigdy”, „prawdziwe”, „najważniejsze”, ,jedyny” - już na poziomie słownikowym narracja dowartościowuje i absolutyzuje ten męski związek. Ma ona i aspekt cielesny:

Kamil zrozumiał, że Kątskiemu chodzi naprawdę o niego, i wyczuł w tym jakąś wzruszającą słabość, wziął go więc serdecznie za rękę i począł mówić jakby do siebie, jak to bywało jeszcze kiedyś w Warszawie. [...] Zdumiał się, że czuje się silniejszy od niego, i zarazem wzmogła się w nim rzewność, jakby Kątski był stary albo, sam o tym nie wiedząc, potrzebował, by go wesprzeć [BS, s. 39].

Żadna z postaci kobiecych Balu u senatora nie została uchwycona w tak czułym geście, tak empatycznej i cielesnej relacji z mężczyzną. W scenie pożegnania Kamila z Bronką wyjaskrawia się aseksualny i fizyczny dystans między obojgiem: „na nic już nie było czasu, pocałował ją więc tylko po bratersku w oba policzki [...] Bronka pogładziła jego mundur [...] pociągnęła go za guzik" [BS, s. 35]. Pocałunek ma więc braterski charakter, a dotyk Bronki oddziela od ciała ubranie. Fizyczny kontakt między mężczyznami wyraża natomiast żywe emocje: serdeczność, wzruszenie, troskę; ich rozmowy dotyczą spraw wielkiej wagi: powołania, talentu, twórczości.

\section{Przedmiot estetyczny}

Jeden ze sposobów ukazywania kobiecej obecności w twórczości poetyckiej Lechonia eksploatuje jej estetyczność i literalnie wręcz traktuje kobietę jako dekoracyjny element scenografii w świecie przedstawionym wiersza. Na próżno jednak szukalibyśmy obrazów kobiecego ciała; w zasadzie nie spotykamy w tej poezji opisu kobiecej cielesności, ani tym bardziej afirmacji kobiecej seksualności. Kobieca obecność sprowadzona została do wybranych jej sygnałów, znaków estetycznych właśnie, ale niezwiązanych $\mathrm{z}$ cielesnością. Poetycka narracja jest wybiórcza, rozwarstwia postać kobiecą na ciało i zewnętrzne atrybuty (ubranie, dodatki, perfumy) - koncentruje się na nich, poza cielesnością. W wierszu Mochnacki Lechoń przedstawia wizję koncertu fortepianowego, który rzeczywiście miał miejsce w Metzu w roku 1832. Treść utworu stanowi rozemocjonowana gra Mochnackiego 
i problematyka obsesyjnej polskiej pamięci. Czytelnika uwieść też ma koncept sugestywnej gry-opowieści, której dramatyzmowi odpowiada tok wiersza. Według poetyckiej wizji Lechonia, Mochnacki spogląda na publiczność własnego występu; tę znajdującą się blisko wirtuoza stanowią kobiety: „A tu bliżej woń perfum, dam strojonych sznury". Poza tą konstatacją, która rejestruje tylko pobieżnie estetyczny wymiar obecności licznych dam (strojność, woń perfum - woń perfum ma tutaj wymiar estetyczny, nie zmysłowy, należy bardziej do ekskluzywnego, eleganckiego entourage’u kobiecości bez nawiązania do erotyzmu), dalej nie zaprzątają one uwagi Mochnackiego. Oko patrzącego „zdejmuje” tylko płytką, efektowną warstwę rzeczy, nie zatrzymuje się na osobach. Emocje budzą żołnierskie mundury i poruszenie się kirasjera siedzącego w kącie sali. Bohater Lechonia dwukrotnie powraca do obrazu jego postaci, widzi go wyraźniej, oddzielonego od reszty publiczności. Żołnierze, mundury żołnierskie i kirasjerski hełm pełnią tu symboliczne role: odwołują się do pamięci walk narodowowyzwoleńczych i polskiej idei niepodległościowej, nawiązują też do stereotypowej męskości. Kobiecie przeznaczył zaś Lechoń rolę uzupełnienia scenografii świata przedstawionego, drugoplanowość. W Mochnackim kobieta pojawi się raz jeszcze w mglistej wizji, w biedermeierowskich dekoracjach sali, jako partnerka do tańca w ogłupiającym, sennym sztajerze, bez osobowości, w zasadzie bez twarzy („w czyjejś twarzy dołki”), bardziej jako suknia i jej zapach („I zapach białej sukni, ubranej w fijołki”); tylko tyle.

Do tego obrazu nawiązuje wizja Polski roztańczonej, uteatralizowanego mitu narodowego w jednym z najważniejszych wierszy Karmazynowego poematu - Pitsudskim. Przedmiotem w tańcu - bo nie podmiotem, tu taniec pełni podmiotową rolę i jest figurą polskiej historii - są kobiety: tancerki w mazurze - „białe polskie panienki”, wiejskie dziewczęta w sznurach korali i pastelowe francuskie margrabiny ${ }^{15}$. („Jasne panienki ze dworu”" ${ }^{\prime 16}$, to jeden ze stałych Lechoniowych motywów, powracają nie tylko w liryce, ale i w recenzjach teatralnych; jest to odbicie jednego ze stereotypów narodowej wyobraźni, fantazmatu dziewczęcej niewinności i szlachetnego urodzenia.)

${ }_{15}$ Zob.: Ireneusz Opacki, Wokół „Karmazynowego poematu” Jana Lechonia, „Pamiętnik Literacki” 1966, z. 4, s. 471-473. Opacki wykazuje istnienie motywu tańca jako metaforycznie znaczącego w Karmazynowym poemacie. Wydaje się, że motyw ten jest stałą figurą wyobraźni Lechonia; w jednym z fragmentów Balu u senatora znajdujemy nawiązującą do niej scenę: „Pod przymrużoną powieką widział mgłę, w której kolory sukien i dźwięki walca mieszać się poczęły z coraz rosnącym zapachem, nagle jasno, okrutnie, jakby stał z boku własnego życia, a zarazem z bólem, jakby je przeżywał na nowo, przypomniał sobie Okęcki wszystko, o czym chciał zapomnieć”. Jan Lechoń, Bal..., op. cit., s. 15.

${ }_{16}$ Por.: Jan Lechoń, Cudowny świat teatru. Artykuty i recenzje 1916-1962, PIW, Warszawa 1981, s. 42. 
I gdzieś kończy muzyka jakiś bal spóźniony.

Pod lila abażurem mrugają lampiony.

Białych sukni w nieładzie senność, ciepło, zmiętość

I piersi, krągłych piersi obnażona świętość,

I mazur, biały mazur w ogłupiałej sali:

Dziś! Dziś! Dziś! Wieś zaciszna i sznury korali.

Roztańczyła się sala tęgim nóg tupotem.

Hołubce o podłogę walą, biją grzmotem,

Białe panny i panny niebieskie, różowe

Przelotnie a zalotnie przechylają głowę

I mówią czarnym frakom: „Przyjdźcie do nas jutro”

I podają im usta za podane futro.

A kiedy świt różowy przez żaluzje wnika,

Dla siebie, nie dla gości, gra jeszcze muzyka.

Menuetem się cichym wiolonczela żali,

I białe margrabiny przychodzą z oddali.

Na liliowych oparach spływają bez słowa,

I panier rozłożyła markiza liliowa,

Kawaler podszedł blady. Pani tańczyć każe!

I tańczą hafty, sprzączki, koronki, pliumaże.

Mgławicowość, nierealność obrazu odsyła do stylistyki romantycznej wizji, ale w obrazie Polski roztańczonej trzeba też zobaczyć cielesność wydrążoną, tańczące puste suknie, taniec chocholi ${ }^{17}$. I znów kobiety to tylko barwne plamy ubiorów, „hafty, sprzączki, koronki, pliumaże”, krynoliny włączone $\mathrm{w}$ taniec - korowód historii, poddane mu jako pozbawione treści, estetyczne figury. Oko patrzącego/poety, podobnie jak w Mochnackim, zatrzymuje się na powierzchni, jaką stanowią ubrania; fascynuje go przepych haftek, zapinek, pióropuszy, z pietyzmem odnotowuje rozmaite elementy stroju, jednocześnie rezygnując z obrazu cielesności. Bo wers „I piersi, krągłych piersi obnażona świętość" stanowi, co prawda, trybut na rzecz cielesności, ale jej zmysłowość i materialność osłabiono przez sakralizację. Obraz ciała odsłania seksualność podmiotu, podczas gdy ubranie, okrycie go odsuwa konteksty seksualne; u Lechonia estetyczny wymiar kobiecości realizuje się w zasadzie poza kobiecością, przez to, co ją zakrywa i co samodzielnie, jako rekwizyt,

${ }^{17}$ Taniec chochołów to zapośredniczona od Wyspiańskiego powtarzająca się w liryce i prozie Lechonia figura pustki i zepsucia. Podczas pobytu Lechonia w Nowym Jorku, kiedy z rozmaitych przyczyn narastał jego negatywny stosunek do Francji, zapisywał w Dzienniku: „Wczoraj u Zosi Kochańskiej Jacques Dupont opowiadał o balach paryskich z taką ekscytacją, jakby naprawdę to było jakieś życie sztuką, coś nowego i coś czego powinniśmy Paryżowi zazdrościć. Marie Laure, Marie Blanche, Lili Pastre - ależ to Chochoły i ich bale to tańce Chochołów" (notatka z 7 lutego 1956). Znamienne, że to zepsucie Francji dokonuje się przede wszystkim w kobietach - bal chochołów to bal kobiecy. Jan Lechoń, Dziennik, t. III, PIW, Warszawa 1993, s. 662-663. 
mogłoby stać się podmiotem fetyszyzującej wyobraźni. (Osobne poetyckie ujęcie stanowi ironiczny obrazek spotkania „białych panien i panien niebieskich, różowych” z „frakami” i znamionującej próżność oraz zepsucie handlowej heteroerotycznej wymiany: usta za podane futro.) Taniec i ubiór stanowią powtarzający się klucz stylistyczny służący wprowadzeniu kobiety w świat wiersza Lechonia. Widzimy, że poeta dysponuje jedynie kilku chwytami oswajania kobiecości, a jego wyobraźnia nagina się do jej ujęć tylko w stałym kompleksie znaczeń: taniec-ubiór. Jakże często jest to kobieta (kreacja kobiecości) zdefiniowana przez ubiór, wsparta na ubiorze, jak na rusztowaniu rozpoznanego sensu: Bronka z Balu u senatora $\mathrm{w}$ „dobrze skrojonym, ale ubogim popielatym kostiumie i taniusim kapeluszu, który sama sobie zrobiła”, kobieta, „której nie stać na kir i żałoby” (wiersz Wielki Piątek), Wanda Landowska „w sukni białej” (Sarabanda dla Wandy Landowskiej), Erynie „w kapeluszach z wstążkami, w rękach niosąc cynie” (Erynie) i inne ${ }^{18}$.

Dodatkowo ubrania podkreślają porządek płci - w odniesieniu do mężczyzn mówią o roli społecznej, polskości i obcości. Wszak fraki, zaangażowane w merkantylny pocałunek z kolorowymi pannami, znamionują męskość zdeprecjonowaną, obcą, pustą (samo ubranie). Taką samą reprezentuje „blady kawaler” tańczący na rozkaz margrabiny w krynolinie. Zupełnie inne znaczenia uosabia kontuszowy szlachcic Zagłoba z wiersza Sejm. Jego postać oznacza polskość i męskość; dumny i efektowny wkracza cały w bieli na salę polskiego sejmu:
Gdy do Sali wszedł sejmowej z wielkim animuszem, Gwałt uczynił pan Zagłoba białym swym kontuszem.
Za pas słucki rękę włożył, srebrną ma deliję,
Drzwi otwarły się z hałasem. Łuna! Łuna bije!
Powciskani w ław szeregi zerwą się posłowie
I spojrzeli na się wzajem, w krzyżach czując zdrowie,
Gdy tymczasem on, wylotów odrzucając, stąpa,
Aż zadrżała, zaskrzypiała polska chata skąpa.
Poszedł cichy szmer po frakach, poszedł po żakietach,
Rozglądają się biskupi strojni w fijoletach.

Rola, jaką Zagłoba odgrywa w tym poetyckim obrazie polskiego sejmu, wiąże się z jego indywidualizmem i spektakularną fizycznością - ubrany w biały kontusz, w pasie słuckim, okryty srebrnym płaszczem, „wylotów odrzucając”, dumnie kroczący, odcina się od reszty. Na tle „fraków” i „żakietów" sylwetka i polski strój Zagłoby wybijają się kontrastem znaczeń obcości i swojskości, słabości i siły, tężyzny i zepsucia. W tych antytezach wypowiada

${ }^{18}$ Wśród reprodukowanych rysunków Lechonia powtarzają się szkice postaci kobiecych w sukniach z epoki, w ogromnych kapeluszach zasłaniających twarz. Zob.: Jan Andrzej Kosiński, Album rodzinne Jana Lechonia, Czytelnik, Warszawa 1993, s. 237. 
się, oprócz osobistej tęsknoty poety za mirażem szlacheckości, w zasadzie ponadczasowy polski konflikt kontusza i fraka, zdrowej swojskości i zagranicznej degrengolady. Po stronie tego rodzaju zepsucia znajdują się też kobiety. Bohater wiersza:

Zasępionych zastał w sali, zagadanych górnie,

Wieńce kokot na galeriach, posłów na koturnie,

Budżetowej gwar dyskusji, szelest enuncjacji.

Kobiety znajdujące się w tym poetycko wykreowanym sejmie, wśród koturnowych posłów, w sercu politycznej dyskusji, to „wieńce kokot”. $\mathrm{W}$ ujęciu poety te, można rzec, girlandy z kobiet zdobią i uzupełniają sale koncertowe (w wierszu Mochnacki) i sejmowe. Są częścią scenografii, ale nie pełnią przy tym żadnej istotnej roli. Jeśli literalnie potraktować poetycki opis, to świat przedstawiony Sejmu jawi się jako nazbyt groteskowy: jedyne kobiety w polskim sejmie to kokoty i to w większej liczbie, skoro poeta każe nam widzieć „wieńce kokot na galeriach” ${ }^{19}$.

Estetyzacja to szyfr dyskursu homoseksualnego stale obecny w twórczości Lechonia. Odnajdujemy go, czytając Dziennik:

Od pewnego czasu stoi na rogu 59 i 5 Avenue, ukryta we wnętrzu Plazy, kobieta bardzo dobrze ubrana, w wielkim kapeluszu z woalką, długonoga, złotowłosa - la folle de Manhattan. Całymi dniami wystaje w tym samym miejscu, jakby chowając się za tą secesyjną woalką, mówiąc coś do siebie czy do kogoś, jakaś Laura z Kordiana, Idalia w Fantazego, wariatka romantyczna i stylowa - dziw, że właśnie w Nowym Jorku nieromantycznym oszalała na tak stylowo - tak poetycznie. Zna ją już całe miasto, jest ona częścią nowojorskiego pejzażu w jego najbardziej snobistycznym centrum i muszę powiedzieć - mimo całego współczucia dla jej nieszczęścia - że ozdabia ten Manhattan czarem jakiejś bajki, legendy, jakby protestując swoją pozą, załamaniem rąk przeciw twardości tego miasta, jego rzekomej rzeczywistościº (notatka z 18 czerwca 1953).

${ }^{19}$ Jak bardzo kłóci się owa wizja z przekazem historii, uzmysławia wywód Marii Janion: „Badaczki, co znamienne: cudzoziemki, zwracają uwagę na szczególne znaczenie wzorów szlacheckich w mentalności kobiet polskich. Sytuacja porozbiorowa zmusiła kobietę z wyższych warstw społecznych do współdziałania u boku mężczyzny, a nie tylko do odgrywania roli «istoty mu podległej», pisze Nora Koestler w rozprawie Kobiety polskie między spoteczeństwem tradycyjnym a nowoczesnym. Świadomość poczesnego miejsca kobiet w «czasach Rzeczpospolitej szlacheckiej znajdowała oparcie w statusie stanu szlacheckiego, a następnie umocniła się dzięki wspólnemu z mężczyznami udziałowi w ruchu oporu przeciw wrogom Polski». Dotyczyło to najpierw szlachcianek, a potem także kobiet z inteligencji. Zarysowała się tu wyraźnie różnica w stosunku na przykład do kobiet niemieckich. «Tak więc kiedy niemiecka burżuazja, w jej drobnomieszczańskim wcieleniu, była raczej przeciwna emancypacji kobiet, Polki przejęły coś ze swobody szlacheckich republikanek». Kobiety polskie w większym stopniu czuły się obywatelkami. Te okoliczności historyczne wzmagały znaczenie tradycji rycerskich w Polsce". Maria Janion, Kobiety..., op. cit., s. 78-79.

${ }^{20}$ Jan Lechoń, Dziennik, t. III, op. cit., s. 144. 
Bohaterka Lechonia pełni być może rolę tragiczną, ale staje się ona (ta tragiczna rola) przedmiotem uwagi jedynie na tyle, na ile jest w stanie pełnić jednocześnie funkcję estetyczną. Atmosfera tragizmu, a właściwie tylko związana z tragizmem nastrojowość, ujęta w jedynie powierzchownej konstatacji łączy się z obrazem i estetyką przykuwającej wzrok przesady. Kobieta jest „bardzo dobrze ubrana” (znaczy tu chyba ekskluzywnie, bogato, co w ujęciu Lechonia oznacza prawie zawsze zaletę charakteru), „w wielkim kapeluszu z woalką, długonoga, złotowłosa”. Lechonia dyspozycja do zajmowania się ubiorem, wydobywania estetycznego wymiaru rzeczy nakłada się tu na brak dociekliwości związanej z kobiecością.

Kobieta jako Inny pozostaje poza światem emocji poety. Nazywając rzecz prostodusznie: nie obchodzi go, jak głęboko, możemy ocenić, czytając dziennikowy zapis jednej z obserwacji amerykańskich:

Różne rodzaje czarności murzyńskiej dają w zestawieniu z innymi kolorami niebywałe kombinacje, które zbyt mało inspirują malarzy i dekoratorów. Dziś znowu uderzyła mnie subtelność tych odcieni, gdy patrzyłem w subwayu na Murzynkę czekoladową w czarnym kostiumie, spod którego widać było bluzkę matoworóżową. Miała kapelusz z ciemnej słomki, ubrany kwiatami wszystkich możliwych pastelowych odcieni, jak cynie, i przewiązany woalką gazową jasnoróżową. Było to prawdziwe plastyczne arcydzieło ${ }^{21}$ (notatka z 14 maja 1950).

Można tu podziwiać Lechonia jako kolorystę, dla mnie uderzająca jest jednak bezwzględność tego utrwalonego w dziennikowej notatce uprzedmiotowienia i tkwi chyba ona w zupełnie nieświadomym, można rzec niewinnym, go (tego uprzedmiotowienia) przeprowadzeniu i wyartykułowaniu. Lechoń patrzy tu na człowieka, kobietę, jak patrzy się na dekorację, grę kolorów rzeczy, ślizga się po powierzchni wyglądu, zafrapowany innością podglądacz, taksujący obserwator malarskiego dzieła, bez czułości. Można powiedzieć, że Lechoń widzi tutaj „coś”, zjawisko estetyczne, kolorystyczne, a nie „kogoś”. Kluczową rolę w jego oglądzie odgrywa inność rasowa i płciowa oraz status społeczny, stawiające czarnoskórą kobietę poza nawiasem płynącego z empatii, dociekliwego zainteresowania. Wydźwięk zapisu Lechonia jest też taki: jedynie estetyzm jest zdolny wydźwignąć tę sytuację (podróż metrem i obserwacja „zwykłej kobiety”) poza jej prozaiczność. W innym miejscu ujawnia się seksistowsko-rasistowski charakter zapisu:

Baudelaire aż do swej katastrofy wspomagał swą Mulatkę - olbrzymkę, która zdaje się była jedyną jego długotrwałą kochanką. [...] Kombinacja pasji do potwornych bab czarnoskórych i zupełnej bezradności wobec pulchnych z krwi i mleka rubensowskich piękności, jak pani Sabatier, jest bardziej komiczna niż zasmucająca ${ }^{22}$ (notatka z 23 marca 1950).

\footnotetext{
${ }^{21}$ Ibidem, t. I, s. 295.

${ }^{22}$ Ibidem, s. 248.
} 
W obrzydzeniu i pasji autora widać, jak trzy rodzaje inności: cielesna, rasowa i płciowa, nakładają się na siebie i wzajemnie wzmacniają. W miejscu estetyzowanego poetyckiego ujęcia, eteryczności barwnej plamy, sukni sygnalizującej kobietę mamy wizerunek dosadny i odpychający. Niewielki, ale znaczący opis podobnie widzianej kobiecości spotkamy w jednym z najważniejszych wierszy Karmazynowego poematu - Jacku Malczewskim (1918). Figuracja kobiecości jest tu swobodną kontaminacją kobiecych figuracji malarskich Jacka Malczewskiego i postaci Młynarki z baśni dramatycznej Lucjana Rydla Zaczarowane koło, kobiet wyraźnie cielesnych, o zasugerowanym erotyzmie ${ }^{23}$. Didaskalia Rydla wprowadzają Młynarkę z całym jej erotyzmem: „Wchodzi Młynarka. Piękna, czarnobrewa, trzydziestoletnia kobieta, rysy kształtne, proste, wargi pełne, różane. Ubrana po wiejsku, kraciasto, na szyi korale, na głowie czerwona chustka, spod niej koło uszu wystają końce obciętych włosów”. Bohaterka Rydla, żona znacznie starszego od niej Młynarza, opętana jest miłością do pracującego w młynie, zobojętniałego na jej uczucie Jaśka.

\author{
MŁYNARKA \\ $[\ldots]$ \\ I w ocach nie widzę świata, \\ I pali mnie, jako świeca \\ Przytknięta na zywe ciało...
}

Pełna namiętności i zazdrości, aby pozyskać jego miłość, decyduje się - za namową diabła Kusego - na „krwawy ślub”, zabójstwo Młynarza i zaangażowanie w nie chłopaka. Wspólne morderstwo przesądza o przyszłości obojga; Młynarka traci zmysły, a Jasiek ginie w topieli.

Śmiech Młynarki rozlega się coraz bliżej. [...] Niemal równocześnie dwaj hajducy wprowadzają Młynarkę i zostają w progu. - Młynarka boso, w przyodziewie podartej w strzępy, chustka czerwona, obsunięta na tył głowy, rozwiązana pod szyją; włosy w największym nieładzie, rozwichrzone spływają na czoło i skronie. Jeden rękaw od koszuli na pół udarty, odsłania obnażone ramię.

GŁOS MŁYNARKI

Laboga! O! Topielice!...

${ }^{23}$ Lechoń znał raczej dramaty Rydla, nie zaś ich przedstawienia sceniczne. „Nie będzie zapomniane w literaturze, że Zaczarowane koło powiedziało pierwszy raz w teatrze bajkę polską o Borucie, powiedziało to, jak się mówi bajkę dziedziczną: z wielkim wzruszeniem, najlepszych słów dobierając, że panowie magnaci i jasne panienki ze dworu, i młynarki z opętanych młynów idą w taniec - tylko w taniec, ale jakże dworny, jaki piękny, jak rwący oczy kolorem, pod jakąż mistrzowską muzykę wiersza”. Jan Lechoń, Cudowny świat..., op. cit., s. 41-42. Recenzję opublikowała „Nowa Gazeta” w 1918 (nr 182), pierwodruk Jacka Malczewskiego miał miejsce w „Pro arte et studio” w styczniu 1918 roku (z. 9). 
Jaśku... wciągną cię do wody...

Pójdźwa... Nie stój nad tą wodą,

Urywa i wpada w śmiech spazmatyczny

Poruszane przez diabła, obracające się coraz szybciej, koła młynów tworzą upiorną scenografię zakończenia utworu. Lechoń odtwarza tę aurę, dekorację topieli i demonicznych młyńskich kół w ostatnich wersach Jacka Malczewskiego:

Derwidzie! Hej! Derwidzie! Złe czeka nad wodą.

Bezmyślna, jurna dziewka bezwstydnie odkryta

Tęczami sennych skrzydeł po czole go muska,

Do ust mu lepkie wargi przykłada czerwone.

Hej! Młyny! Idą młyny - i woda w nich pluska.

W wierszu Jacek Malczewski ów demonizm buduje przede wszystkim kobieta - uskrzydlona jak chimera z przedstawień Malczewskiego, cielesna i namiętna jak Młynarka.

Podobną wymowę kobiecej fizyczności odnajdziemy w wierszu Jan Potocki ${ }^{24}$. Jest ona metaforą ciemnej demonicznej namiętności, antytezą wzniosłości i metafizycznej tęsknoty. Podobnie jak w pozostałych ujęciach, tak i tutaj, cielesność wprowadzona została przez ubranie i taniec (może flamenco):

Rozsnuj mi szale hiszpańskie czerwone -

Taniec mi zatańcz: mą młodość szczęśliwą.

O tak, tak właśnie - przeginaj się w skręty,

Co nic nie znaczą, a wszystkim być pragną.

Czerwonouste Carmeny niech nagną

Ust rozchylonych, tęsknoty mej świętej!

W niewielu ujęciach wyobraźnia Lechonia dziedziczy piekło młodopolskich (anty)fascynacji, mityzacji, demonizacji, obrzydzenia ${ }^{25}$. Kobieca cielesność możliwa jest do zaakceptowania jedynie jako transgresyjna, androgyniczna, męska. „Litka Romaszkan (Aleksandra Orme), niegdyś fascynująca chłopięca urodą dziewczyna z Warszawy"26 - zapisuje Lechoń w Dzienniku.

${ }^{24}$ Pierwodruk: „Skamander” 1921, z. 5-6.

${ }_{25}$ Zob.: Wojciech Gutowski, Nagie dusze i maski: O mtodopolskich mitach mitości, Wydawnictwo Literackie, Kraków 1992.

${ }^{26}$ Jan Lechoń, Dziennik, t. I, op. cit., s. 302. 


\section{Figury pożądanej transgresji}

Szczególny „rodzaj” kobiet w świecie Lechonia stanowią aktorki. Uosabiają one figury transgresji wychodzące poza stereotyp historycznie zdefiniowanej kobiecości. Podobnie rzecz się ma z kobietami „niezwykłymi”, o znaczących albo utrwalonych w literaturze nazwiskach (artystki, władczynie itp.). Spektakularność, monumentalność czy skrajność tych postaci umieszcza je poza tym, co moglibyśmy nazwać zwykłą kobiecością. Nazwisko, idea czy artystyczna biografia stają przed fizyczną osobą, ciałem i pożądaniem, które „odkobiecają się” przy ich pomocy, przekształcają w sposób dowolnie modelowany przez wyobraźnię podmiotu.

Spotkanie na ławce w parku z posiadaczką cudnego mopsika o kolorze i wdzięku syjamskiego kota. Rozmowa najpierw po angielsku, później po francusku. Okazuje się, że dama miała matkę Polkę, krewną Bichetty i Dolly Radziwiłł, sama jest Włoszką, żoną Amerykanina, aktora Donalda Cooka, który jest partnerem Tallulah Bankhead. Dama zna mnóstwo Polaków, m.in. nieboszczyka ambasadora i Ignasia Skrzyńskich. Psy są jej hobby: ma 12 bokserów i hodowlę poolies węgierskich ${ }^{27}$ (notatka z 27 maja 1950).

Ta krótka dziennikowa relacja daje podstawę do tego, aby jej autora nazwać po prostu snobem, ale rzecz jest bardziej skomplikowana. Zainteresowanie Lechonia w rzeczywistości pomija osobę, nie zatrzymuje się też nad jej cielesnością, więcej wiemy o fizyczności mopsika niż spotkanej kobiety. Czytelnik zyskuje natomiast wiedzę na temat narodowości, koligacji, znajomości i stanu posiadania kobiety; dowiaduje się również, że spotkana włada językami, szczyci się dostępem do życia artystycznego Brodwayu (Tallulah Bankhead była znaną aktorką), ma tzw. znajomości („zna mnóstwo Polaków”) i hodowlę drogich psów. Widać, że te właśnie cechy wzbudziły ekscytację Lechonia i przesądziły o istotności spotkania. Na podobnej zasadzie trafiają na karty Dziennika nieliczne kobiece postaci: monarchinie, prezydentowe, artystki, kobiety po prostu znane. Otoczka prestiżu, ekscentryczności i artyzmu jest rodzajem przepustki do świata tekstów Lechonia, jest też pretekstem, aby poza tym światem pozostawić ich realistycznie ujęte doświadczenie kobiecości - cielesność.

Aktorstwo niejako z definicji wiąże się z niezwykłością, wzniosłością, przerysowaniem, z wychodzeniem poza stereotypowe role. Tak, poprzez postać, której pierwowzorem jest Helena Modrzejewska, charakteryzuje aktorską sztukę kobiecą Susan Sontag:

Grając w sztuce, w jednej z wielkich sztuk, stawałaś się lepsza, niż byłaś w istocie. Wypowiadałaś jedynie słowa wypolerowane, niezbędne, uwznioślające. Wyglądałaś zawsze tak pięknie, jak tylko mogłaś wyglądać - z pomocą pewnych forteli - w swoim

${ }^{27}$ Ibidem, t. I, s. 306-307. 
wieku. Każdy twój gest nasycony był wielkim, rozrzutnym znaczeniem. Czułaś, że to co musisz wyrazić na scenie, wydoskonala jakoś ciebie samą ${ }^{28}$.

„Aktorowi nie wolno być sobą, nie wolno mieć jednej twarzy dla garderoby i dla sceny, musi za każdym razem być inny, za każdym razem nowy." - pisał Lechoń w felietonie krytycznym $O$ aktorach teatru Rozmaitości ${ }^{29}$. Możliwość takiego przeistoczenia musiała być dla niego pociągająca, skoro zrealizował swoje pragnienie gry aktorskiej i wcielił się w rolę Astolfa w Odludkach i poecie Aleksandra Fredry. Aktorstwo tworzy sytuację transgresji, która w wypadku tej konkretnej biografii (Lechoń jako „prawdziwy aktor” w tej sztuce, jako ta postać) wydaje się jednym z bardzo niewielu momentów jawnego publicznego wkroczenia w Inność, a ta konkretna sztuka sceniczna daje tej inności niepodważalne alibi. Aktorstwo kobiece wiąże się z odrzuceniem tradycyjnej roli związanej z płcią, oznacza graniczność, dynamiczność, potencjalność kobiecości, z którą łatwiej patriarchalnemu homoseksualiście się komunikować. Aktorka wychodzi poza prozaiczną kobiecość - odtwarzając rolę, wchodzi w niezwyczajność (tę Lechoń zawsze podziwia i ceni) - a może nawet przestaje wyglądać jak kobieta; wchodzi w iluzję przebrania, wykorzystuje konwencję maski. Aktorstwo jest dziedziną, w której - dla Lechonia - kobiety występują na równi z mężczyznami:

I dlatego dla wszystkich, którzy nie słyszeli Królikowskiego czy Rychtera, nie widzieli Modrzejewskiej czy Wisnowskiej, nazwiska te niczym są, jeno dźwiękiem szacownym bez treści. I dlatego trzeba koniecznie czcić aktorów za życia, kwiaty im rzucać i bić brawa, hucznie święcić jubileusze. Każdy aktor jest ostatnim w swoim rodzie, każdy z nich jest poetą, który książki nie mógł napisać3 ${ }^{30}$.

W myśl poglądów idealistycznych estetyków pierwszej połowy XIX wieku, aktorstwo ma charakter artystowski: „Aktorki i aktorzy, podobnie jak inni artyści, mają nadawać realne kształty ideałom, z którymi, tak jak poeci, nawiązują kontakt dzięki natchnieniu" "31. Lechoń wydaje się podzielać takie rozumienie aktorstwa również, co ważne, w odniesieniu do aktorstwa kobiecego.

I tak samo najśliczniej szczerej, najbujniej lirycznej, najpoetyczniejszej i najpiękniejszej wielkiej artystce pannie Szyllinżance nikt nie ukazał wysokiego celu aktorskich zadań i ślicznej poezji, nawet nie wielkiego, pompatycznego repertuaru. Jakież cudne tony dobyłaby z Czechowa, gdyby ją ku niemu poprowadzić, jaka wymarzona byłaby z niej „szalona Julka”, jaka wojewodzina Amelia! Tymczasem zaś reżyserowie ani się starają

${ }^{28}$ Susan Sontag, W Ameryce, przel. Jarosław Anders, Czytelnik, Warszawa 2003, s. 52.

${ }^{29}$ Jan Lechoń, Cudowny świat..., op. cit., s. 43.

30 Ibidem, s. 31.

${ }^{31}$ Dariusz Kosiński, Sztuka aktorska w polskim piśmiennictwie teatralnym XIX wieku, Wydawnictwo Uniwersytetu Jagiellońskiego, Kraków 2003, s. 56. 
zacierać i łagodzić ostrych podźwięków jej głosu, nikt nie tonuje ruchów, które czasami zbyt są, doprawdy, nieopanowane i twarde. Ale pp. reżyserowie jak głaz są obojętni, gdy chodzi o rozwój czyjegoś talentu, liczą na sukces samej już zewnętrzności p. Szyllinżanki, pragną, aby wieczorem tak zachwycała w Carewiczu, jak rano zachwyca w kawiarni ${ }^{32}$.

Teatralnym kreacjom aktorskim poświęcił Lechoń recenzje, które złożyły się na obszerny tom Cudowny świat teatru. Osobny zbiór korespondencji stanowią listy Lechonia kierowane do aktorki Anny Jackowskiej, która swoją postawą tworzy model pozastereotypowej kobiecości. Tak pisze o niej Roman Loth:

Mocno tkwiła w życiu środowiska artystycznego, związana z nim nie tylko swoją pozycją aktorki, ale w równej mierze osobami brata [Leon Schiller - B.C.] - już wówczas wybijającego się reżysera, i męża - znakomitego artysty scen polskich. Liczne przyjaźnie i znajomości łączyły ją ze światem literackim, a od chwili drugiego zamążpójścia - za dyplomatę, Tadeusza Jackowskiego - również z politycznym ${ }^{33}$.

Do wierszy dedykowanych kobietom (choć Lechoń nie poświęca osobnego wiersza, przykładowo, własnej matce) należy Alina ${ }^{34}$, utwór kierowany do aktorki Aliny Gryficz-Mielewskiej zmarłej w 1946 roku. Wiersz nawiązuje do sytuacji, która rzeczywiście miała miejsce - Lechoń obdarował spotkaną przed wojną w Sopocie aktorkę pękiem goździków ${ }^{35}$. Poetyckie wspomnienie tej sytuacji wprowadza też postać nieżyjącej kobiety:

W mym sercu jak w bursztynie na zawsze przetrwały,

Choć ziemią przywalone: twych włosów ozdobny

Kask złoty i kształt cudny twojej ręki białej,

I głos twój, do żadnego w świecie niepodobny.

Mamy oto cielesność, ale pozbawioną realizmu, ozdobną, stylizowaną: złoty kask włosów, cudny kształt białej dłoni, a podwójnie już nierealną, bo unieważnioną przez śmierć, zastygłą, unieruchomioną we wspomnieniu „jak w bursztynie". Na plan pierwszy wiersza wybija się raczej poetycki koncept: wspomnienie zmarłej aktorki, trzymającej w ręku bukiet goździków otrzymanych kiedyś od poety, które wywołane zostaje widokiem sprzedawanych na ulicy takich samych kwiatów. Powracający motyw kwiatów i śmierć bohaterki wiersza tworzą dla tej figuracji estetyczną ramę uwznioślenia.

${ }^{32}$ Jan Lechoń, Cudowny świat..., op. cit., s. 44.

33 Roman Loth, Wstęp, [w:] Jan Lechoń, Listy do Anny Jackowskiej, Czytelnik, Warszawa 1977 , s. 5 .

34 Pierwodruk: londyńskie „Wiadomości” 1953, nr 30.

35 Wspomina o tym Dziennik: „Rymy do wiersza o goździkach, które kupiłem w Zoppotach spotkanej tam Alinie Gryficz”. Jan Lechoń, Dziennik, t. III, op. cit., s. 113. 
Wątek estetyzmu w powiązaniu z figuracją kobiecości podkreśla Sarabanda dla Wandy Landowskiej, wiersz dedykowany światowej sławy klawesynistce i pianistce, z którą poeta się przyjaźnił (napisał artykuł o płytowych nagraniach Landowskiej ${ }^{36}$; planował nawet książki o artystce). Wiersz ten uznał Lechoń za swoje estetyczne credo $^{37}$. Tak pisze o Sarabandzie... Anna Węgrzyniakowa:

W Sarabandzie dla Wandy Landowskiej koncert klawesynowy przedstawia Lechoń jako projekcję pragnień w idealny (właściwie platoński) obszar doznań estetycznych. Swoistą wielowymiarowość „życia snem” sugeruje ruchowa, sceniczna konstrukcja świata przedstawionego: klawesynistka „przechodzi trawę miękką”, „pieści loki Galatei”, „po białej klawiaturze lekko biją [jej - B.C.] bose stopy”; proces tworzenia jawi się jako odnajdywanie formalnej doskonałości dla intensywnie przeżywanych ról (Wenus, Święta Cecylia, Galatea, Ofelia). Choć w konstrukcji tej wizji podmiot - reżyser spektaklu podkreśla właściwą sarabandzie pałacową dworskość scenerii (gobeliny, kandelabry, rekwizyty pasterskie), rzeczywistym miejscem koncertu jest nocny ogród. Solistce towarzyszy orkiestra „niewidzialnych młodych chłopców”, na platoński typ erotyki wskazuje symbolika motywów (do ogrodu wchodzi bohaterka drobnym menuetowym krokiem w białej sukni... i wypływa ,jak Ofelia cała w bieli”), cała sytuacja koncertu jest wyśniona („Śpi w śnie srebrnym pogrążona, rozmarzona Wenus drżąca”; „Niechaj teraz w sen się zmienia to, do czego myśl się wzniosła”), a doznania estetyczne przechodzą w wymiar metafizyki ${ }^{3}$.

Projekcja pragnień w idealny obszar doznań estetycznych, biała kobieca suknia, repertuar mitycznych ról kobiecych sytuujących się poza fizyczną kobiecością, orkiestra „niewidzialnych młodych chłopców” tworzą gęstą, przestylizowaną, można powiedzieć kampową, scenerię świata przedstawionego odpowiadającą wyobraźni homoerotycznej. Estetyzm Lechonia realizuje się w wyobraźniowych wizjach, powoływaniu i powtarzaniu znaczących, symbolicznych atrybutów. Stylizacyjnej gęstości, wypełnieniu i nadmiarze świata przedstawionego odpowiada narracja podmiotu zwielokrotniona, powracająca do podobnych ujęć, motywów, charakterystyczna dla dyskursu homoseksualnego ${ }^{39}$.

Jeden z bardziej estetycznie, wizualnie wyrazistych poetyckich obrazów kobiety (tu: kreacji scenicznej) znajdziemy w Pitsudskim:

Czarna Rachel w czerwonym idzie szalu drżąca

I gałęzie choiny potrąca idąca -

Nikogo nie chce budzić sukni swej szelestem,

36 Jan Lechoń, Arcykoncert niewidzialny, „Wiadomości” 1952, nr 10.

37 Anna Węgrzyniakowa, Tworzywo Lechoniowej poezji („musi umrzeć w życiu, co ma powstać w pieśni”), [w:] red. Ireneusz Opacki, Szkice o twórczości Jana Lechonia, Skamander, t. 7, Uniwersytet Śląski, Katowice 1991, s. 27.

${ }^{38}$ Ibidem, s. 26-27.

39 Zob.: German Ritz, Dyskurs ptci w ujęciu porównawczym, „Teksty Drugie” 1999, nr 5. 
I idzie w przód jak senna, z rąk tragicznym gestem, I wzrokiem, błędnym wzrokiem gasi mgieł welony,

I świt się robi naraz. I staje zlękniony.

Wiersz został zadedykowany Helenie Sulimie, która - występując w czarnej sukni i czerwonym szalu - stworzyła pierwszą i słynną kreację Racheli w Weselu Stanisława Wyspiańskiego (premiera przedstawienia miała miejsce w marcu 1915 roku w Teatrze Rozmaitości w Warszawie ${ }^{40}$ ); ona też wprowadziła Lechonia w świat teatru. Gra kolorów jest w tym obrazie Racheli wyrazista, odbiega ona od pastelowości plam oznaczających „białe panny, panny niebieskie, różowe" z uprzednio cytowanego fragmentu wiersza. Czarne tło sukni, przecinająca je czerwień szala skontrastowana z nasyconą, głęboką zielenią gałęzi choiny rysują postać charakterystyczną, mediumiczną, złowróżbną, nawiązującą do modernistycznych wizerunków kobiecości.

\section{Metafora nieobecności}

Znacznie ciekawsze od odtwarzania patriarchalnego wzoru są te typy kreacji kobiecości w dziele Lechonia, gdzie do głosu dochodzi motywacja ukrywającej się seksualności (homoseksualności). Zbiór poetycki Srebrne i czarne potocznie nazywany jest zbiorem o miłości i śmierci. Tak tę poetycką książkę, stawiając ją w kontekście Karmazynowego poematu, charakteryzuje Joanna Kisielowa: „Wysoki ton liryki obywatelskiej, znany czytelnikom rewelacyjnego debiutu poety, $\mathrm{w}$ drugim i ostatnim międzywojennym tomie Lechonia ścichł do szeptu poszukiwań tożsamości jednostkowej, do rozważań o życiu i śmierci, Bogu i grzechu, miłości i cierpieniu"41. Próżno jednak w owym zbiorze szukać upłciowionego obiektu miłości, Lechoń ukrył go poza wskazaniami gramatyki, nie określił rodzajowo. I tak, na przykład, wiersz Nieczystość pozwala się czytać zarówno jako zapis fascynacji homo-, jak i heteroerotycznej.

Jedno długie spojrzenie, ach! Ileż potrafi

Rzucone w moją stronę prawie nieostrożnie.

Ach! Jakąż jest rozkoszą oglądać bezbożnie

To wszystko, czego nie ma na twej fotografii.

[...]

Noc z tobą - to jest jedno, co jak haszysz działa,

Tylko jedno, w co można wierzyć bezprzytomnie.

I nie wiem, czy jest miłość oprócz twego ciała,

I wiem, że mnie nie kochasz, że zapomnisz o mnie.

${ }^{40}$ Roman Loth, Wstęp, [w:] Jan Lechoń: Poezje, op. cit., s. 21.

${ }^{41}$ Joanna Kisielowa, Retoryka i melancholia. O poezji Jana Lechonia, Wydawnictwo Uniwersytetu Śląskiego, Katowice 2001, s. 104. 
Tylko jeden wiersz, Na niebo wyptywaja biatych chmurek żagle, wprowadza żeńską formę gramatyczną adresata, choć składniowo i rytmicznie tak samo odpowiadałaby temu wersowi forma męska:

\author{
Na niebo wypływają białych chmurek żagle, \\ Od twojej płynie strony niebieska fregata \\ Nie do mnie, nie od ciebie. I poczułem nagle, \\ Że już nigdy nie będzie, jak zeszłego lata. \\ Noc przyjdzie księżycowa i w twoim ogrodzie \\ Na srebrnej trawie cienie ułoży ogromnie. \\ A później będzie koła rysować na wodzie, \\ Gdy będziesz szła ogrodem nie ze mną, nie do mnie.
}

Utwór zadedykowany został Wandzie Serkowskiej, z którą znajomość Lechonia została przez badaczy wyeksploatowana w celu kształtowania biografii poety zgodnie z heteroseksualną, w duchu takiej miłości, normą. (Syn Wandy Serkowskiej wielokrotnie dementował w prasie istnienie takowego związku.) Co charakterystyczne, jest to wiersz o utracie, nieobecności, niespełnieniu i przemijaniu.

Inne utwory z tomu Srebrne i czarne nie wprowadzają żeńskiej formy gramatycznej i, podobnie, są wierszami nieobecności, pustki po osobie. Trzeba je czytać jako szyfrację emocji homoerotycznej, która może wypowiedzieć się jedynie jako uniwersalne, nienacechowane płciowo uczucie, nie może jednak wprowadzić uosobionego obiektu miłości do wiersza. Rozważania o nieobecności kobiety w homoseksualnym świecie poetyckim otwiera utwór Spotkanie, wprowadzający postać Danta i Beatrycze. Oto fragment:

I tylkom jakiś dziwny posłyszał szum rzeki, A później, później Danta ujrzałem na moście.

„Tyżeś to, ty, mój mistrzu! Dlaczego tak blady

I czemu taki dziwny niepokój cię żarzy?

Przychodzę cię ubłagać o sekret twej twarzy.

Nic nie wiem. Zabłądziłem. I proszę twej rady.

On to rzekł, czy rzekł księżyc, czy woda to rzekła,

Padłem, głowę ukrywszy rękami obiema:

„Nie ma nieba ni ziemi, otchłani ni piekła,

Jest tylko Beatrycze. I właśnie jej nie ma”.

Wygłosowa fraza to jeden z częściej cytowanych fragmentów wierszy Lechonia, zaś mityczna Beatrycze jest głęboko i w wielu odniesieniach przyswojoną przez kulturę. Beatrycze jest ideałem kobiety, celem drogi, przewodniczką. Jednak w utworze Lechonia to Dantemu, mistrzowi powierza 
pierwszoosobowy podmiot swoje wyznanie, jego błaga o radę i jego twarz jest dla niego znacząca. Mit Beatrycze został przez poetę wywołany, jednak nie konkretyzuje się w tym wierszu w żaden sposób, nie występuje jako przedmiot refleksji, ani tęsknoty, jest figurą praktycznie pustą. Ten paradoks obecności i nieobecności kryje się nie tylko w pojemności, uniwersalności mitu Beatrycze, indywidualizuje go (paradoks, nie mit) sam poeta przez swoją ukrywaną, zawikłaną i budującą kompleks winy homoseksualną biografię. Wers: „Nic nie wiem. Zbłądziłem. I proszę twej rady” wyraża to doświadczenie i nawiązuje do realności. Paradoks (nie)obecnej Beatrycze opisuje kulturę heteroseksualną, w której obowiązuje; istnieje „tylko Beatrycze” - idealny, mistyczny obiekt miłości, który jednak znajduje się poza realnością biografii i doświadczenia wielu. Zatem jest tylko kobieta i właśnie jej nie ma, bo nie może stanowić celu wędrówki, nie może przewodniczyć homoseksualiście. Stąd tragiczny gest („Padłem, głowę ukrywszy rękami obiema”) prowadzący do pointy wiersza, zdradzający samotność homoseksualisty pozbawionego (w heteroseksualnej kulturze) sensu, celu, porządku, który nie widzi swojej drogi. Nie ma Beatrycze, bo ten prywatny mit Dantego w wypadku poety nie istnieje, nie aktualizuje się, w jego świecie nie ma kobiecej gwiazdy przewodniej, nie ma Ariadny. Stąd też na poziomie formalnym, gramatycznym nieobecność kobiety w zbiorze.

W literackim świecie Jana Lechonia spotkamy kobiety stereotypowe, wyblakłe, pozbawione psychologicznej głębi. Jeśli zaś pojawiają się one w centrum uwagi poety, to jedynie jako przedmiot teatralnego gestu, obiekt w atrakcyjnej oprawie ubioru, postać wyniesiona wysoką pozycją towarzyską albo obdarzona efektownym artystowskim rysem. Homoseksualne umotywowanie tekstu każe poszukiwać kobiecości w tym, co aseksualne, sublimacyjnie odcieleśnione.

\section{BIBLIOGRAFIA}

Ambros Aleksandra, Mężczyźni bez kobiet, „Literatura na Świecie” 1992, nr 3.

Bataille Georges, Historia erotyzmu, przeł. Tadeusz Kania, Oficyna Literacka, Kraków 1992. Gutowski Wojciech, Nagie dusze i maski: O mtodopolskich mitach miłości, Wydawnictwo Literackie, Kraków 1992.

Iwasiów Inga, Kobiecość w tekście homoerotycznym, [w:] red. Lidia Wiśniewska, Kobiety w literaturze. Materiały z II Międzyuczelnianej Sesji Studentów i Naukowców z cyklu „Świat jeden, ale nie jednolity”, Wyższa Szkoła Pedagogiczna, Bydgoszcz 1999.

Janion Maria, Bogini Wolności (dlaczego rewolucja jest kobieta), [w:] eadem, Kobiety i duch inności, Wydawnictwo Sic!, Warszawa 2006.

Kisielowa Joanna, Retoryka i melancholia. O poezji Jana Lechonia, Wydawnictwo Uniwersytetu Śląskiego, Katowice 2001. 
Kłosińska Krystyna, Ciało, pożądanie, ubranie: O wczesnych powieściach Gabrieli Zapolskiej, „eFKa”, Kraków 1999.

Kosiński Dariusz, Sztuka aktorska w polskim piśmiennictwie teatralnym XIX wieku, Wydawnictwo Uniwersytetu Jagiellońskiego, Kraków 2003.

Kosiński Jan Andrzej, Album rodzinne Jana Lechonia, Czytelnik, Warszawa 1993.

Lechoń Jan, Arcykoncert niewidzialny, „Wiadomości” 1952, nr 10.

Lechoń Jan, Bal u senatora: Fragmenty nie ukończonej powieści, Czytelnik, Warszawa 1981. Lechoń Jan, Cudowny świat teatru. Artykuty i recenzje 1916-1962, PIW, Warszawa 1981. Lechoń Jan, Dziennik, t. I, PIW, Warszawa 1992.

Lechoń Jan, Dziennik, t. II, PIW, Warszawa 1992.

Lechoń Jan, Dziennik, t. III, PIW, Warszawa 1993.

Loth Roman, Wstęp, [w:] Jan Lechoń, Listy do Anny Jackowskiej, Czytelnik, Warszawa 1977.

Loth Roman, Wstęp, [w:] Jan Lechoń, Poezje, Zakład Narodowy im. Ossolińskich, Wrocław 1990.

Opacki Ireneusz, Wokót „Karmazynowego poematu” Jana Lechonia, „Pamiętnik Literacki” 1966, z. 4 .

Ritz German, Dyskurs ptci w ujęciu porównawczym, „Teksty Drugie” 1999, nr 5.

Sobolczyk Piotr, Kobieta w (literackim) świecie gejów, [w:] red. Grażyna Borkowska, Lidia Wiśniewska, Beatrycze i inne. Mity kobiet $w$ literaturze $i$ kulturze, słowo/obraz/terytoria, Gdańsk 2010.

Sontag Susan, W Ameryce, przeł. Jarosław Anders, Czytelnik, Warszawa 2003.

Węgrzyniakowa Anna, Tworzywo Lechoniowej poezji („,musi umrzeć w życiu, co ma powstać w pieśni”), [w:] red. Ireneusz Opacki, Szkice o twórczości Jana Lechonia, Skamander, t. 7, Uniwersytet Śląski, Katowice 1991. 